\title{
SHOP FLOOR-LEVEL CONTROL OF MANUFACTURING COMPANIES: AN INTERVIEW STUDY IN FINLAND
}

\author{
Henri Tokola ${ }^{1}$, Eeva Järvenpää ${ }^{2}$, Tapio Salonen ${ }^{3}$, Minna Lanz $^{2}$, Mikko Koho $^{3}$, Esko Niemi ${ }^{1}$ \\ ${ }^{1}$ Aalto University School of Engineering, Department of Engineering Design and Production, Finland \\ 2 Tampere University of Technology, Department of Mechanical Engineering and Industrial Systems, Finland \\ 3 VTT Technical Research Centre of Finland, Finland \\ Corresponding author: \\ Henri Tokola \\ Aalto University School of Engineering \\ Department of Engineering Design and Production \\ Puumiehenkuja 3, 02150 Espoo, Finland \\ phone: +348504331091 \\ e-mail: henri.tokola@aalto.fi
}

Received: 21 December 2014

Accepted: 12 February 2015

\begin{abstract}
This paper publishes the results of interviews regarding shop-floor-level control of 18 Finnish manufacturing companies. The interviews had 17 open questions relating to demand characteristics, shop floor-level control issues, production flexibility, inventory control, and potential development areas. In order to get insights from the interviews, this paper analyses the answers from the interviews and categorises them into typical answers. The companies that were interviewed are also categorised as small companies with their own end products, subcontractors, or large companies with their own end products, and the emphasis of the analysis is on how companies differ in their shop floor-level control. The results show that different types of companies have different characteristics. Small companies are characterised by constant workflow, seasonal trends in demand, and the use of forecasts. Subcontractors have great daily variation in their demand and processing times. Large companies tend to focus on inventory issues.
\end{abstract}

KEYWORDS

demand forecasting, shop floor control, production flexibility, inventory control, interview.

\section{Introduction}

It is well known, as stated e.g. by Hayes and Wheelwright [1], that different production volumes have different optimal types of production. In large product-oriented companies, process-like production is most efficient, whereas in subcontracting companies, the variety of products makes batch production more economical. This paper adds to this information, and it studies, through interviews, how small companies, subcontractors, and large companies differ in their shop floor-level control. The interviews are part of the LeanMES project, which aims to find out how different companies can implement lean and scalable MES (Manufacturing Execution Systems). The interviews help this by increasing the knowledge about the needs of companies. The preliminary results of all the interviews were studied in another publication, by Järvenpää et al. [2]. However, it does not consider the shop floor-level results in detail, as is done in this paper. It also includes only seven company interviews, which were all OEMs, whereas this paper presents results based on a total of 18 Finnish manufacturing companies.

The aim of the paper is to analyse the results of the interviews and find out how companies differ in their shop floor-level control. The interviews included questions about the demand characteristics, shop floor control issues, production flexibility, inventories, and potential development areas. The exploratory analysis shows how different types of companies have different types of shop floor-level control and associated issues.

The rest of the paper is organised as follows. Next, Sec. 2 presents a literature review regarding production control in different types of companies. 
Section 3 presents the actual interview questions and describes how the interviews were organised. In Sec. 4, the results of the interviews are shown. On the basis of the results, Sec. 5 discusses the differences between the different types of companies. Finally, Sec. 6 draws conclusions.

\section{Literature review}

The earlier research literature gives us several hints about the differences between manufacturing companies. As stated earlier, production volumes define the optimal type of production [1]. Thus, different types of production have different problems. The companies can also be distinguished by their position in the supply chain. There the bullwhip effect (also called the Forrester effect) increases the demand variation seen by the companies upstream in a supply chain, e.g. by subcontractors [3]. Tokola and Niemi developed a model that shows how the problems in production depend on the production volume and number of products [4]. Their model suggests that companies with small numbers of products encounter problems with capacity, whereas companies with large numbers of products may have problems with inventories. Milgrom and Roberts give an overview of the differences in the characteristics of mass production and modern, flexible production [5]. They state e.g. that mass production is characterised by long production runs, high inventories, specialised skill jobs, and make-to-stock control, whereas new modern and flexible production is characterised by short production runs, low inventories, cross-trained workers, and make-to-order control.

Although earlier research has studied the differences on a strategic level, the research related to the tactical shop floor level is scattered. Abernethy and Lillis have a paper regarding the impact of manufacturing flexibility [6]. They state that manufacturing flexibility has been studied much more at a strategic level rather than at the manufacturing level. Veen-Dirks studies the relationships between production environments and control systems [7]. He states that empirical research in the area is scarce, especially at the production level. Davies et al. stress that best practices are not clearly defined in the research papers [8]. Karmarkar et al. study the production processes, product complexity, and number of products in different industries [9]. Related to our research, they state that MRP systems are more probably used in batch production. Ichniowski et al. conclude that worker management tools such as employ- ee participation in problem-solving teams and training give substantially better worker performance [10].

The differences between different types of companies were studied earlier using interviews. Lundvall et al. studied the effect of the size of a manufacturing firm on its technical efficiency [11]. Not surprisingly, they conclude that the size of the firm has a positive effect on technical efficiency. In a similar study, Van Biesebroeck states the same about the efficiency of a large company and shows how it is unlikely that small companies will grow into large companies [12]. This may be due to the fact described earlier that different types of companies have different types of optimal production processes. It is hard to change between different processes.

Finnish companies are also studied in the earlier literature. A study similar to ours was done by Voss et al. [13]. They studied the differences between companies in Finland, Germany, the Netherlands, and the UK. They conclude that none of the companies they considered in Finland were world-class manufacturers, but most of the companies in Finland were categorised as contenders or promising companies, which were good in practice. They also write that small companies are able to rely on informal practices and thus achieve high performance. Another paper where the companies in Finland are studied is that of Timilsina et al. [14]. They conclude that flexibility is more important for smaller companies than for larger companies. This paper, however, does not consider shop floor-level issues such as inventory control methods or types of variations, which are considered in the present paper.

\section{Interviews}

\section{Sample selection}

The present study is based on data collected from interviews conducted among manufacturing companies located in Finland. The companies are grouped into three categories, which are a small company with its own end product (less than 250 employees), a subcontractor, and a large company with its own end product (more than 250 employees). Henceforth in this paper these are referred to as the small company, subcontractor, and large company, respectively. The interviewees included people in production manager, production engineer, planner, and worker positions. The actual numbers of companies and interviewees are shown in Table 1. Their positions cannot be distinguished in the answers. 
Management and Production Engineering Review

Table 1

Distribution of interviewees by position and type of company.

\begin{tabular}{l|c|c|c|c|c}
\hline & & \multicolumn{3}{|c}{ Interviewees } \\
\hline & Companies & Production engineer or manager & Production planner & Worker & Total interviewees \\
\hline Small (own product) & 4 & 4 & 1 & 3 & 8 \\
\hline Subcontractor & 7 & 7 & 4 & 5 & 16 \\
\hline Large (own product) & 7 & 8 & 2 & 6 & 16 \\
\hline Total companies & 18 & 19 & 7 & 14 & 40 \\
\hline
\end{tabular}

Table 2

Open questions used in the interviews. All the questions were put to the managers and production planners. The questions marked $*$ were also put to the workers.

\begin{tabular}{|c|c|}
\hline Area & Question \\
\hline \multirow{3}{*}{ Demand characteristics } & 1. How are the near future forecasts done? \\
\hline & 2. How much does the demand change? How is this handled? \\
\hline & 3. How often are there rush orders when compared to all orders? \\
\hline \multirow{9}{*}{ Shop-floor control } & 4. How are the rush orders handled in production? ${ }^{*}$ \\
\hline & $\begin{array}{l}\text { 5. Is there any single machine that is used to control the whole production (bottleneck } \\
\text { control)? }\end{array}$ \\
\hline & 6. Do you know the standard times of the processes? \\
\hline & 7. How much do the processing times vary? ${ }^{*}$ \\
\hline & 8. How is the work-in-process controlled? \\
\hline & $\begin{array}{l}\text { 9. Are there unexpected daily changes in production? How often? [ ] Customised orders, [ ] } \\
\text { rescheduling, [ ] missing parts/tools, [ ] quality problems. * }\end{array}$ \\
\hline & 10. How are the customised products handled in production? \\
\hline & 11. If there are problems in the production, how are they handled on the shop floor? ${ }^{*}$ \\
\hline & 12. Is it possible to begin the production even if the product is not fully designed? \\
\hline \multirow[t]{3}{*}{ Production flexibility } & $\begin{array}{l}\text { 13. How can the production be adjusted on a daily or hourly basis? Is it possible for workers } \\
\text { to balance the production by themselves? }{ }^{*}\end{array}$ \\
\hline & 14. Do you have extra capacity? Is it possible to move jobs to another work station? ${ }^{*}$ \\
\hline & 15. How can the workers be moved from one station to another? ${ }^{*}$ \\
\hline Inventories & 16. How are the inventories controlled? ${ }^{*}$ \\
\hline Development opportunities & $\begin{array}{l}\text { 17. Where are the greatest development opportunities in production control? [ ] Better fore- } \\
\text { casts, [ ] workload balancing, [ ] worker movement, [ ] anticipation of long processing times, } \\
\text { tardiness and breakdowns, [ ] inventory levels, [ ] other, please specify. } *\end{array}$ \\
\hline
\end{tabular}

\section{Interview questions}

The interview, consisting of 17 questions, was designed to gather information on the following aspects of production: demand characteristics, shop floor control issues, production flexibility, inventory control, and potential development areas. The part of the interview studied in this paper is part of a larger interview that also included questions related to production planning systems, KPIs, and Lean principles. This paper, however, focuses only on shop floor-level control. The questions used in the interviews are listed in Table 2. It was planned that all the questions would be put to the managers and production planners and only some to the workers. However, because of time limitations, some questions were skipped in the actual interviews.

\section{Data analysis}

The interviews, consisting mainly of open answers, were taped and transcribed. Because the answers were open, they tended to be long, and thus the answers were first simplified by writing down the main points from the open answers. After that, the main points were clustered on the basis of the main themes of the answers. These clusters of main themes are the results of the interviews, and they are described next, in Sec. 4.

\section{Results}

\section{Demand characteristics}

Questions 1-3 were about demand characteristics. 21 answers about demand forecast methods were 
collected (question 1). In three cases (two small companies, one large company), the forecasts were made for quarters or the year, mainly using sales data. In six cases (all subcontractors), the companies used clients' forecasts to forecast the production. In five cases (one small company, one subcontractor, three large companies), the companies forced the demand to follow the production capacity, which was constant. In five cases (two subcontractors, three large companies), the companies used frozen schedules to handle the variation in demand.

20 answers about demand variability were collected (question 2). In four cases (three small companies, one subcontractor), the companies faced seasonal trends in their demand. In six cases (three subcontractors, three large companies), there were significant daily, weekly, or monthly variations in demand. In 10 cases (four small companies, four subcontractors, two large companies), miscellaneous methods that were used to tackle the variation were described. These methods included lay-offs, inventories, extra capacity, and trainees.

22 answers about rush jobs were collected (question 3). In eight cases (seven subcontractors, one large company), rush jobs formed more than $10 \%$ of all orders. In 10 cases (one small company, three subcontractors, six large companies) rush jobs were rare. In three cases (two small companies, one large company), there were no rush jobs at all. Additionally, in three large companies, inventories were used to deal with rush jobs.

\section{Shop floor control issues}

Questions 4-12 were about shop floor control issues. 13 answers about handling rush jobs were collected (i.e. question 4). In three cases (one small company, two large companies), the rush jobs were handled using overtime work. In six cases (three small companies, three large companies), there were processes for handling rush jobs. In four cases (two subcontractors, two small companies), it was common to pre-empt current work because of rush jobs.

12 answers about bottleneck control were collected (question 5). In two cases (one small company, one subcontractor), there was no visible bottleneck thinking. In two cases (one small company, one subcontractor), the bottleneck changed over time. In eight cases (one small company, two subcontractors, five large companies), there was a clear bottleneck in the production.

23 answers about standard times were collected (question 6). In three cases (two small companies, one subcontractor), the standard times were not known at all. In 15 cases (one small company, eight subcontractors, six large companies), the standard times were known. In the other five cases (two small companies, one subcontractor, two large companies), the distributions of the processing times were collected and known.

15 answers about variations in the processing time were collected (question 7). In three cases (three large companies), the variation was smaller than or equal to $25 \%$ of the average. In nine cases (three subcontractors, six large companies), the variation was significantly larger. In two subcontractor answers, the amount of variation depended significantly on the worker. In three cases (one small company, one subcontractor, one large company), the variations in the processing time could not be estimated.

15 answers about the control of work-in-process (WIP) were collected (question 8). In four cases (one small company, two subcontractors, one large company), the WIP was controlled by selecting the next job using due dates. In three cases (two small companies, one large company), the WIP was controlled using a pull control measure such as CONWIP. In three cases (three large companies), the WIP control was realised by selecting the next job from the queue. In four cases (three small companies, one subcontractor), production followed a weekly schedule. In the case of one large company, production planning released the jobs into the production.

21 answers about daily problems were collected (question 9). 16 of the answers were about the customisation of orders. In four of the answers (two small companies, one subcontractor, one large company), there were no customised orders. In eight cases (three subcontractors, five large companies), customised orders occurred monthly. In five cases (one small company, two subcontractors, five large companies), customised orders occurred weekly or more often. 16 answers concerned rescheduling. In three of the cases (two small companies, one large company), rescheduling took place rarely or never. In two cases (one subcontractor, one large company), rescheduling occurred monthly. In five cases (one small company, three subcontractors, two large companies), rescheduling occurred weekly. In five cases (one small company, two subcontractors, two large companies), rescheduling occurred daily. 21 of the answers concerned missing parts or tools. In all of them, the problem was missing parts rather than tools. In five of these cases (one small company, two subcontractors, two large companies), missing parts were a problem monthly or more rarely. In seven cases (two small companies, three subcontractors, two large companies), the problem of missing parts occurred weekly. In nine cases (five subcontractors, four 
large companies), missing parts were a daily problem. 21 answers were about quality problems. In six cases (one small company, three subcontractors, two large companies), quality problems occurred rarely. In seven cases (two small companies, three subcontractors, two large companies), quality problems were monthly problems. In eight cases (five subcontractors, three large companies), quality problems occurred daily.

Eight answers about customisations were collected (question 10). All the answers (two small companies, three subcontractors, three large companies) were about customisation processes. According to all three of the subcontractors' answers the foreman handles the customisation problems. In all three answers from large companies, the customisation is seen from the drawings.

13 answers about problem solving were collected (question 11). In eight cases (four small companies, two subcontractors, two large companies), problem solving was done together with the foremen. In five cases (one small company, one subcontractor, three large companies), the notification was written into the companies' manufacturing execution system (MES) in the event of problems.

Eight answers were collected about starting the production even though the design is not finished (question 12). In two cases (one subcontractor, one large company), starting a job was not possible if the design was not finished. In six cases (one small company, five large companies), starting was possible even though the design was not fixed yet.

\section{Production flexibility}

Questions 13-15 were about production flexibility. Question 13 was about how the production can be adjusted daily or hourly. 27 answers to that question were collected. In 10 cases (three small companies, four subcontractors, three large companies), the foremen made the decisions concerning production adjustments. In 10 cases (two small companies, four subcontractors, four large companies), the workers could adjust the production themselves. In six cases (five subcontractors, one large company), overtime work was used to adjust the production.

Question 14 asked about extra capacity. 26 answers to that question were collected. In 16 cases (four small companies, 10 subcontractors, two large companies), there were extra machines. In two cases (one subcontractor, one large company), the subcontractors of the company were those who had the extra capacity. In eight cases (two subcontractors, six large companies), there was no extra capacity at all.

Question 15 asked about the movement of workers. 22 answers to that question were collected. In
14 cases (seven small companies, one subcontractor, six large companies), the workers were cross-trained and could work in several parts of the production. In six cases (one small company, four subcontractors, one large company), there were problems with the know-how of the workers.

\section{Inventories}

Question 16 was about inventory control. A total of 18 answers to that question were given. In six cases (three small companies, three subcontractors), inventories were controlled using the average storage time as a metric. Kanban bins were used in three cases (one subcontractor, two large companies). Vendormanaged inventories (VMIs) were used in two cases (both large companies). Other individual solutions than those described were used in seven cases (one subcontractor, six large companies). These other solutions include e.g. bulk materials, no inventories, and sets.

\section{Potential development areas}

Question 17 was about potential development areas in production. A total of 35 answers was given. The answers from the small companies were the following: three yes answers for better forecasts, two for workload balancing, and two for better inventory levels. The answers from the subcontractors were the following: eight yes answers for better forecasts, 11 for workload balancing, five for worker movement, seven for anticipation, seven for inventory levels, and three for others. The answers from the large companies were the following: seven yes answers for better forecasts, six for workload balancing, six for worker movement, six for anticipation, nine for better inventory levels, and one for others. Other answers included better NC programs, making products as planned, more output using fewer workers, and information movement between planning and production. An overview of the results of question 16 is shown in Fig. 1.

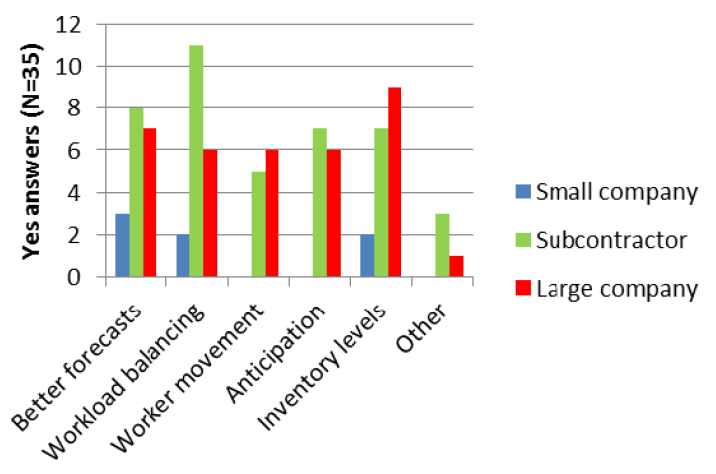

Fig. 1. Possible development areas. 


\section{Discussion}

In this section, the results shown in the previous section are analysed further. The aim is to find out how different companies differ in their shop floorlevel control.

The results from the Demand part (questions 1-3) give the following insights. The small companies often used their own forecasts and had seasonal trends in their demand. The subcontractors used forecasts from their clients and had significant daily variation in demand. The large companies mostly used constant capacity or a frozen timetable, and they had significant daily variation in demand.

The shop floor control issues (questions 4-12) do not provide conclusions as clear as those in the demand part above. The small companies tend to use pull or a weekly schedule to control their WIP. They have problems with missing parts or quality weekly or less frequently. Otherwise, it is hard to say anything about the other questions. At the subcontractors, standard times are generally known, but they show variation as the worker affects the processing time significantly. Rescheduling takes place daily or weekly. Customised products are handled using the foreman's experience. In the large companies, bottleneck thinking is generally used; there is often a bottleneck station that is controlled. Estimates of standard times are known. WIP is controlled just by taking the next order from the queue. Customised products are rare; the large companies tend to produce items using customised mass production, where products are often modular. If there are customised products, workers see the customisation from the drawings. If there are problems, a notification about the problems is entered into the control system. It is also possible to start orders and e.g. make some parts before the design is completed.

The results about production flexibility (questions 13-15) raised the following issues. In the small companies, there are extra machines to deal with e.g. breakdowns of machines and workers are crosstrained. At the subcontractors, flexibility is achieved using overtime work. There are extra machines but there might be problems with know-how. In the large companies, there are no extra machines, but people are still cross-trained.

Several issues were raised about inventory control (question 16). In the small companies and sub- contractors, the inventory yield is monitored and adjusted. In the large companies, there were many inventory strategies that were used.

In development areas (question 17), the small companies tended to need better forecasts. The subcontractors needed better workload balancing, whereas the large companies usually needed better inventory levels. The above-mentioned differences are collected in Table 3.

Generally, the small companies had varying strategies to deal with variation and variation did not seem to be a severe problem. Their problems related to seasonal trends, but production did not seem to be a problem. Handling rush jobs, bottleneck thinking, and estimating standard times were used in some of the small companies, but not in most of them.

With the subcontractors, the variation was a major problem. Rush jobs were common, the skills of individuals affected the processing time, and skills were scattered. The flexibility needed to tackle these problems was achieved using rescheduling, overtime work, and/or extra machines. Similarly as with the small companies, handling rush jobs and bottleneck thinking only occurred in some companies.

The large companies seemed to know what they wanted from the shop floor level control. There was no extra capacity, as with the small companies and subcontractors. Instead, the variation was handled using inventories and cross-trained workers. Inventories were a significant problem in the production and several methods were used to tackle the problems with inventories. The way in which the daily variation was handled varied.

When compared to the ideas found from the literature in the review part in Sec. 2, the above insights can be understood better. In the literature review, it was found that small companies are technically worse than large companies $[11,12]$. This is supported by our results, as it appears that the production is less organised in small companies and subcontractors than in large companies. If subcontractors are considered, the bullwhip effect causes the early players in the supply chain to have higher variation in demand than others [3]. Large companies tend to be technically better and often have a process-like production line, all of which are features that cause them to know their process better, as our results outline as well $[1,11,12]$. 
Management and Production Engineering Review

Table 3

Typical answers from different companies. "-" means that no conclusions could be based on the answers because they were too scattered.

\begin{tabular}{|c|c|c|c|}
\hline Question & Small companies & Subcontractors & Large companies \\
\hline Demand forecasts (1) & Own forecasts & Forecasts from clients & $\begin{array}{l}\text { Constant capacity or frozen } \\
\text { schedule }\end{array}$ \\
\hline Demand variability (2) & Seasonal trend & Significant daily variation & $\begin{array}{l}\text { Significant daily variation in de- } \\
\text { mand }\end{array}$ \\
\hline Rush jobs (3) & Seldom & $\begin{array}{l}10-20 \% \text { rush jobs of all or- } \\
\text { ders }\end{array}$ & $\begin{array}{l}\text { Rare, inventories used for rush } \\
\text { jobs }\end{array}$ \\
\hline Handling of rush jobs (4) & - & - & - \\
\hline Bottleneck thinking (5) & - & - & Bottleneck thinking \\
\hline Standard time (6) & - & Standard times are known & Estimates are known \\
\hline Process time variation (7) & - & $\begin{array}{l}\text { Person has a remarkable } \\
\text { effect on processing time }\end{array}$ & - \\
\hline WIP control (8) & Pull, weekly schedule & $\begin{array}{l}\text { The orders are processed } \\
\text { according to the deadline }\end{array}$ & Next order from the queue \\
\hline Customised products (9) & - & - & Seldom \\
\hline Rescheduling (9) & - & Daily/Weekly & - \\
\hline Missing parts (9) & Weekly/Seldom & - & - \\
\hline Quality problems (9) & Weekly/Seldom & - & - \\
\hline $\begin{array}{l}\text { Handling of customised prod- } \\
\text { ucts }(10)\end{array}$ & - & $\begin{array}{l}\text { Foreman deals with the } \\
\text { problems }\end{array}$ & $\begin{array}{l}\text { Workers see the customisations } \\
\text { of parts from the drawings }\end{array}$ \\
\hline Problem solving (11) & - & - & Notification to the system \\
\hline $\begin{array}{l}\text { The product can be start- } \\
\text { ed before design is completed } \\
(12)\end{array}$ & - & - & $\begin{array}{l}\text { The orders are often started be- } \\
\text { fore design is fixed }\end{array}$ \\
\hline Flexibility of production (13) & - & $\begin{array}{l}\text { Flexibility through over- } \\
\text { time hours }\end{array}$ & - \\
\hline Extra capacity (14) & Extra machines & Extra machines & No extra capacity \\
\hline Moving of workers (15) & Often cross-trained workers & Problems with know-how & Often cross-trained workers \\
\hline Inventory control (16) & $\begin{array}{l}\text { Average storage time is mo- } \\
\text { nitored }\end{array}$ & $\begin{array}{l}\text { Average storage time is } \\
\text { monitored }\end{array}$ & $\begin{array}{l}\text { Many strategies: Kanban, VMI, } \\
\text { sets }\end{array}$ \\
\hline $\begin{array}{l}\text { Development } \\
\text { opportunities (17) }\end{array}$ & Better forecasts & Workload balancing & Inventory levels \\
\hline
\end{tabular}

\section{Conclusion}

This paper examines how different types of Finnish manufacturing companies differ in their shop floor-level control. The results of the interview study suggest that there are several differences between small companies, subcontractors, and large companies:

- small companies are characterised by a constant workflow, seasonal trends in demand, and the use of normal forecasts;

- subcontractors have large daily variation in their demand and processing times;

- large companies focus on inventory-related issues. These results are expected or at least easy to understand. Small companies tend to focus on a few products which are mostly produced to order, which makes their demand seasonal. Subcontractors are early players in the supply chain and the bullwhip effect makes the demand seen by them vary. Large companies are usually just assemblers of products with large numbers of components, which makes the inventory control of components crucial.

The results in the paper are exploratory in nature. The results might be biased by the simplifications and clustering performed by the authors. However, the results suggest that there are typical differences between the companies, which could be valuable information for further research. In the LeanMES project, which the present study is part of, the purpose is to use the results to direct the development of new production control tools. In future, the results could also be verified using descriptive analysis.

This research was carried out as part of the Finnish Metals and Engineering Competence Cluster's (FIMECC) MANU programme in the LeanMES project. 


\section{References}

[1] Hayes R.H., Wheelwright S.C., The dynamics of process-product life cycles, Harvard Business Review, 57, 2, 127-136, 1979.

[2] Järvenpää E., Tokola H., Salonen T., Lanz M., Koho M., Tuokko R., Requirements for Manufacturing Operations Management and Control Systems in a Dynamic Environment, In Flexible Automation and Intelligent Manufacturing 2014 (FAIM2014), 2014.

[3] Forrester J.W., Industrial Dynamics (Vol. 2), Cambridge, MA: MIT Press, 1961.

[4] Tokola H., Niemi E., Estimating Short-term Production Planning Challenges in Multi-item Production, 22nd International Conference on Production Research (ICPR 22) at Iguassu Falls, Brazil on 28 July-1 August 2013, 2013.

[5] Milgrom P., Roberts J., Complementarities and fit strategy, structure, and organizational change in manufacturing, Journal of Accounting and Economics, 19, 2, 179-208, 1995.

[6] Abernethy M.A., Lillis A.M., The impact of manufacturing flexibility on management control system design, Accounting, Organizations and Society, 20, 4, 241-258, 1995.

[7] van Veen-Dirks P., Management control and the production environment: A review, International Journal of Production Economics, 93, 263-272, 2005.
[8] Davies A.J., Kochhar A.K., Manufacturing best practice and performance studies: a critique, International Journal of Operations \& Production Management, 22, 3, 289-305, 2002.

[9] Karmarkar U.S., Lederer P.J., Zimmerman J.L., Choosing manufacturing production control and cost accounting systems, In: Measures for Manufacturing Excellence, Kaplan R.S. [Ed.], Harvard Business School Press, Boston, MA, 353-396, 1990.

[10] Ichniowski C., Shaw K., Prennushi G., The effects of human resource management practices on productivity (No. w5333), National Bureau of Economic Research, 1995.

[11] Lundvall K., Battese G.E., Firm size, age and efficiency: evidence from Kenyan manufacturing firms, Journal of Development Studies, 36, 3, 146-163, 2000.

[12] Van Biesebroeck J., Firm size matters: Growth and productivity growth in African manufacturing, Economic Development and Cultural Change, 53, 3, 545-583, 2005.

[13] Voss C., Blackmon K., Hanson P., Oak B., The competitiveness of European manufacturing - a four country study, Business Strategy Review, 6, 1, 1-25, 1995.

[14] Timilsina B., Haapalainen P., Takala J., Effect of company size on manager's perception, Management and Production Engineering Review, 5, 1, 65-73, 2014. 